\title{
The Influence of Individual Psychological Abilities on Managerial Activities of Line Managers
}

\author{
Nadezhda Victorovna Filinova ${ }^{1}$, Sergei Aleksandrovich Bobinkin ${ }^{1}$, Svetlana Valentinovna Matveeva ${ }^{1}$, Olga \\ Urievna Dembitckaia $^{1} \&$ Natalia Sergeevna Akatova ${ }^{1}$ \\ ${ }^{1}$ The Branch of Russian State Social University in Klin, Russian Federation \\ Correspondence: Nadezhda Victorovna Filinova, The branch of Russian State Social University in Klin, \\ Papivina street, 1/20, Klin, Moscow region, 141600, Russian Federation.
}

Received: November 1, 2014

doi:10.5539/ass.v11n7p208
Accepted: December 23, 2014 Online Published: March 16, 2015

URL: http://dx.doi.org/10.5539/ass.v11n7p208

\begin{abstract}
The article talks about the problem of optimization of managerial activities of individual psychological characteristics. In this connection, line managers, taking into account managerial abilities, authoring methodological tool of evaluation and selection of line managers who are able to disclose their managerial potential in socio - professional activity conditions is formulated and tested. This study showed the relationship between the individual abilities and managerial activities of line managers. Analysis of the results of the study revealed that managerial abilities and individual psychological characteristics define the "effective" of managerial activities of line managers.
\end{abstract}

Keywords: managerial abilities, individual psychological characteristics, managerial activity, line manager

\section{Introduction}

In the beginning of XXI century, deep and multifaceted transformations in all spheres of society began to make high demands on the man, his work and personality. There was an urgent need for high quality professionals capable of making independent decisions and act effectively in conditions of high uncertainty and risk. The progressive development of man, his creativity, the ability to independently resolve personal and public problems, was considered as an important factor of progressive development of the modern Russian society.

Knowledge of the laws of the management, of the psychological characteristics of human behavior in the organizations today are considered, essentially, as an integral part of general culture of the specialist's personality in any field. Wherever the future specialist works and what he is doing, he is always included in the "organizations' world" in the management system, occupying a certain place in it (often - a managing place). The condition of his effective activity, and in the end - his life success is the knowledge of organizational and managerial regularities.

Studying the regularities of management activity is associated with fundamental difficulties. Their essence is as follows. Any activity has two aspects - external (observable, explicit) and internal (hidden from direct observation, implicit), objective and subjective. The first one, for obvious reasons is disclosed much better and more complete than the second one. However, in the strict sense it is not a subject of psychological study, it is such an object for the management theory. She, however, without considering the objective content of the managerial activity, its' psychological study and understanding is impossible. Hence there is an urgent problem of finding the optimal proportion, matching externally - objectified characteristics of the managerial activity and the characteristics of its internal - psychological content. This proportion can be established on the basis of two fundamental psychological principles. The first - the principle of the unity of mind and action, according to which the external and internal components of the activity are indissoluble integrity and should be explained for each other through each other. The second - the principle of a two-stage study of the psychological activity. According to it the analysis of the activity must include two successive stages - an analysis of its content and an analysis of its psychological mechanisms. The first stage is associated with the characteristic of the objective content of activity, the second one - with the analysis of subjective, psychological content. These principles are currently peculiar imperatives and set the general direction of the study of any activity. 


\section{Method}

The problem of optimization of professional activity was considered by researchers of various areas of general psychology, personality psychology, social psychology, labor psychology and others. (Abulkhanova-Slavskaya 1980; Ananev, 2003; Bazarov, 2005; Zhuravlev, 2005; Karpov, 2004; Klimov, 1998; Leontiev, 1983; Parigin, 2003; Pryazhnikov and Pryazhnikova, 2004; Rozanova, 2006; Suvorova, 2003, Tolochek , 2005). It should be noted that currently, this question was discussed perhaps in every work on the psychology of management.

The essence of managerial activities of the manager - organizing the activities of others, i.e., "An activity of organizing activities" (an activity of "second order"), so it is called meta-activity. BF Lomov writes: "Individual activity does not exist by itself; it is "woven" into the activities of the society. <..> any individual activity is a part of joint activities" (Lomov, 1981).

According to the hierarchy of power, N. V. Samoukina allocates among executives (managers) two subgroups (Samoukina, 2003):

- $\quad$ Senior executives (top management);

- $\quad$ Mid-level executives (middle management).

If top managers of high level management perform mainly administrative functions, the middle management (line managers) are required to have specialized knowledge and know how to manage people.

In small organizations, line managers can perform all the duties associated with personnel, without any help. But with the growth of the company they are in need of assistance, expertise knowledge and advices of human resources managers, who are involved in human resource management.

It should be pointed to the fact that the line manager must be able not only to manage his subordinates, but also to obey the supreme manager. NA Kurtikov writes: ".... for a successful management of other it is necessary, first of all, to be able to govern yourself "(Kurtikov, 2007). It is for the reason that mid-level manager must manage to combine good special knowledge, management skills and ability to obey; in recent years there is a lot of talk about the lack of this particular category of managers (Alaverdov, 2008).

Considering management activities of line manager we must clarify that middle management is divided into upper and lower levels, but there are no fundamental differences in their work.

The activities of line manager contain the following functions. (Samoukina, 2003):

- Doing connecting activities, in which the line manager should bring the resolutions of top management to his subordinates. If these resolutions are popular among the employees, mid-level manager should explain them, but if they are unpopular or negative resolutions (e.g., reduction of wages or reduction of staff), then the line manager acts as a kind of "buffer" which "takes the hit";

- A high proportion of business communications in the work of line manager (up to $80-90 \%$ of his working time he spends in the mode of oral communication with subordinates and other managers on the organization and coordination of joint efforts);

- Doing different and responsible functions in the technique and mechanism of their implementation communicative, organizational, intellectual, emotional, etc., because along with the managerial, organizational and control activities, line manager has to solve purely professional tasks (negotiate, solve production problems, make and analyze business documents and so on);

- Solving the staff problems- hiring and dismissal of employees, conducting training and certification of the personnel, making personnel decisions, the distribution of prizes, conducting informal events in his unit, "therapeutic" tasks with those employees who are experiencing personal dramas (death of relatives, family illness, divorces and so on.);

- $\quad$ The implementation of a number of short time, detailed actions that require high concentration and ability to move from one activity to another (analyze the documents; communicate with subordinates verbally and by telephone, to interact with customers and partners, to work with business correspondence).

Managerial activities of line manager - is a type of professional activity, the specificity of which is determined by its main and most common task - the need of co-organization of other people's activities towards the achievement of common objectives, and thus to support the principle of the hierarchy (Karpov, 2004). Managerial activity of line manager in general independently of particular types is that it is not only individual, not only joint, but the first and the second simultaneously. Thus appears as a qualitatively unique type of activity, synthesizes the two other main types of activities (individual and joint). Indeed, the managerial activity of line manager by definition means the existence of a number of involves "controlled" subjects, i.e. it is joint. However, it does not cease to be individual, because it requires the implementation of all the components and tools that are 
specific to the structure of individual activity. Moreover, the individual activity of the manager, aimed at solving problems of management, significantly changes; appears in the most extensive form; its complexity and responsibility dramatically increase. Simultaneously the joint activity under the influence of management is built not as a simple co-operation, but in the type of hierarchical organization. Thus, it also becomes more complex and psychologically rich. Therefore, psychologically, managerial activity of the manager is treated as a synthesis of individual and collaborative activities (Karpov, 2004).

In modern conditions, the line manager have new tasks, including improving the governance and searching for new methods and approaches in the field of professional activity. One of the central places in search for reserves for increasing the effectiveness of professional is rightfully given to the research on psychological analysis of the optimization of management in various social and psychological conditions. This leads to the necessity of analyzing the variety of approaches, tactics and strategies that are implemented in the study of the abilities that influence the effectiveness of managerial activities of line managers, both in theoretical and empirical terms.

The difficulties of studying managerial capabilities of line managers are related to the fact that this category of abilities is one of the most difficult in psychology, and is still not disclosed in full. It constantly "escapes" from the disclosure of its nature and dissolves in other psychological concepts - knowledge, skills, intelligence, personality and psychological qualities, mental processes, and others. In Russian psychology the question of connection between the activities and individual activities was studied by a number of well-known authors (Andreeva 2006; Kabachenko, 2005; Karpov, 2004; Morozov, 2008; Platonov, 1972; Rubinstein, 2002; Samoukina, 2003; Shadrikov, 1994). As a result, the concept of capabilities has found its place in the overall structure of psychological concepts. This is - an "intermediate" link between two fundamental psychological categories - activity and personality. So the question of assessment of professional skills of line managers is very actual today, and undoubtedly will remain so in the general problems of the psychology of management.

Studying the managerial activities of line manager, we should notice that like any other activity, it is characterized by different level of its qualitative parameters. This is determined by many characteristics, but primarily it depends on personal, social and professional characteristics of the managers, the need for which is determined by the content and nature of the professional activity. In other words, one of the main qualities of its effectiveness is the specific professional skills. Not only efficiency, but even the possibility of implementing managerial functions depends on the line manager, on his possession of such abilities. In this regard, the concept of the abilities plays a special role in the study of professional activity (Karpov, 2004).

Currently the professional abilities of the subject of labor are still insufficiently studied, and the question of the composition and structure of the professional abilities is not adequately resolved. The practical importance of this question is obvious and is due to the fact that only on the basis of its decision it is possible to develop scientifically proved and constructive procedures for the selection of line managers and their certification and training. B. D. Parigin writes: "It is obvious, however, that the problem of psychological readiness is not confined by specific professional activity in extreme conditions. It is equally important in any professional activity. Hence the importance of psychological support of professional selection and readiness of personnel" (Parigin, 2003). However, today there are only a number, usually weakly consistent with each other, of approaches to the development of this problem.

AB Karpov writes: "The difficulties of studying managerial capabilities... are related to the fact that this category of abilities is one of the most difficult in psychology, and is still not disclosed in full. It constantly "escapes" from the disclosure of its nature and dissolves in other psychological concepts - knowledge, skills, intelligence, personality and psychological qualities, mental processes, and others." (Karpov, 2004). However, to date, there is some general psychological characterization of abilities; its main conditions are as follows.

Abilities - are individual psychological characteristics of the individual, which are condition of successful implementation of any activity and which detect differences in the dynamics of having the necessary knowledge, skills and abilities (Karpov, 2004). Abilities - are not knowledge and not skills of the man, they are internal conditions, and due to them he can more or less successfully master knowledge and skills. Abilities - are mechanisms, mental forms, but knowledge and skills - are mental content, they specific elements of specific picture of the world of a specific individual. Ability is manifested in speed, strength and accuracy of the acquired knowledge and skills building (Karpov, 2003). There are three main features which distinguish the abilities of all other mental phenomena:

- Abilities are - individual psychological characteristics that distinguish one person from another;

- They are only those features that are relevant to the successful implementation of an activity or several activities; 
- Abilities are not reducible to knowledge and skills that are already developed in humans, although they cause the ease and speed of their implementation.

Abilities of line manager - are psychological basis of the success in mastering their professional activities. They are the main condition for the effectiveness of the implementation of administrative functions by the line manager. Abilities - are relatively stable mental properties that are manifested in the individual uniqueness of mental resources (tools) that implement a particular activity (Karpov, 2003). As a result, we can state with a certain degree of probability, that professional abilities - are personality qualities that distinguish one line manager from another according to qualitative and quantitative indicators of success in mastering professional activities.

In the structure of abilities we allocate two main categories -General and special abilities. General abilities - are relatively stable properties of line manager, which appear in the successful mastering of knowledge, in learning and implementing various activities. Special Abilities - are properties of line manager that allow achieving significant results in some form of activity (Karpov, 2003).

Abilities of managerial activity - are individual psychological characteristics of the individual, which in line manager provide the formation of a deliberate sustainable commitment to continuous self-improvement, harmonization of self-development process, progressive upward movement in individual, personal and subjective development and reaching the tops in social and psychological conditions of life. An important condition for the development of abilities is a demand for knowledge, skills and experience in the professional activity. The lack of demand for them is a quality that hampers the development of abilities to managerial activity.

Taking into account the psychological aspects of managerial activities, we have formulated the structure of individual - psychological abilities of line managers working in different socio - professional conditions. The structure of individual - psychological abilities to managerial activity includes two main categories of qualities that are either directly managerial abilities, or indirectly implement the functions of the abilities (i.e. affecting the success of managerial activities, ceteris paribus) (Karpov, 2004). The formulated structure of individual psychological abilities of line managers include the abilities to managerial activities (general and specific managerial skills) and individual - psychological characteristics (biographical characteristics and personality psychological qualities), which help to optimize the managerial work in certain socio - professional conditions.

\section{Results}

To analyze the factors of individual - psychological abilities that influence the effectiveness of managerial activities of line managers we initiated an empirical study in trading companies and subsidiary offices of banks working in Moscow and the Moscow region. As research methods were used: methods of theoretical and historical analysis, generalization and interpretation of scientific data; empirical methods - observation, interview, questionnaires, document analysis, analysis of the research results, analysis of activity results, testing: $16 \mathrm{PF}$ questionnaire R. Cattell; test questionnaire of $\mathrm{H}$. Eysenck (determining the degree of manifestation of the properties of "introversion - extraversion 'and' neuroticism - emotional stability"); questionnaire rating scale of the needs to achieve; exclusive questionnaire for assessing administrative abilities and personal qualities of line managers. The obtained data were statistically analyzed using the Spearman rank correlation method, and Fisher and Kolmogorov-Smirnov criteria.

The total number of participants in the empirical study was more than 287 people aged 25 to 48 years. The group of study consists of 103 line managers working in the branch offices of banks and 95 line managers working in trading companies. To evaluate the results of empirical research we used a group of 89 applicants for the position of line manager.

The study of individual - psychological abilities of line managers included two parts. The first part - the study of the relationship between the effectiveness of managerial activity and professionally important qualities of line managers. The second part - the organization and conduct of competitive selection of the number of applicants, line managers into banks and trading companies, using the results of professiogramms that we received in the first part of the study.

The first group of results is made up of the data of "Efficiency" of the activity of line managers and personal data. The assessment of the relationship between the measures was performed using Spearman rank correlation.

The analysis determined that there is a statistically significant correlation: the "Efficiency" of line managers activities in banks with age $(\mathrm{R}=0,67, \mathrm{p}$-level $=0,000)$, work experience $(\mathrm{R}=0,63$, p-level $=0,000)$; the "Efficiency" of the activity of line managers of trading companies with age $(\mathrm{R}=0,40$, p-level $=0,000)$, work experience $(\mathrm{R}=0,52$, $\mathrm{p}$-level $=0,000)$. 
The second group of results was made up of the data of activity "Efficiency" of line managers and individual psychological features. The assessment of the relationship between the measures was performed using Spearman rank correlation.

The analysis found that there is a statistically significant correlation: "Efficiency" of the activities of line managers of banks with (md) High levels of self-confidence $(\mathrm{R}=0,32$, $\mathrm{p}$-level $=0,000)$, (A) communicability $(\mathrm{R}$ $=0,20$, p-level $=0,010),(\mathrm{C})$ emotional stability $(\mathrm{R}=0,19, \mathrm{p}$-level $=0,019),(\mathrm{H})$ Courage in social contacts $(\mathrm{R}=$ $0,22, \mathrm{p}$-level $=0,007),(\mathrm{Q})$ self-confidence $(\mathrm{R}=-0,18, \mathrm{p}$-level $=0,023),(\mathrm{Q} 3)$ high self-control $(\mathrm{R}=0,17$, $\mathrm{p}$-level $=0,037)$ Emotional instability $(\mathrm{R}=-0,32, \mathrm{p}$-level $=0,000)$, scale of lies $(\mathrm{R}=0,37$, $\mathrm{p}$-level $=0,000)$, achievement motivation $(\mathrm{R}=0,57$, $\mathrm{p}$-level $=0,000)$; "Efficiency" of the activities of line managers of trading companies with (A) communicability $(\mathrm{R}=0,43$, p-level $=0,000)$, (B) Intelligence $(\mathrm{R}=0,23$, $\mathrm{p}$-level $=0,000)$, (E) dominance ( $\mathrm{R}$ $=0,38$, p-level $=0,000)$, $(\mathrm{F})$ expressivity $(\mathrm{R}=0,39$, $\mathrm{p}$-level $=0,000),(\mathrm{G})$ normative behavior $(\mathrm{R}=0,30$, $\mathrm{p}$-level $=$ $0,000)$, (I) Sensitivity $(\mathrm{R}=0,39$, $\mathrm{p}$-level $=0,000)$, (L) suspiciousness $(\mathrm{R}=0,42$, $\mathrm{p}$-level $=0,000)$, $(\mathrm{M})$ Developed imagination $(\mathrm{R}=0,44$, $\mathrm{p}$-level $=0,000)$, $(\mathrm{N})$ diplomacy $(\mathrm{R}=0,45$, $\mathrm{p}$-level $=0,000),(\mathrm{Q} 1)$ Radicalism $(\mathrm{R}=0,34$, $\mathrm{p}$-level $=0,000),(\mathrm{Q} 2)$ nonconformism $(\mathrm{R}=0,35$, $\mathrm{p}$-level $=0,000)$, (Q4) Intensity $(\mathrm{R}=0,44$, $\mathrm{p}$-level $=0,021)$, emotional stability $(\mathrm{R}=0,15$, $\mathrm{p}$-level $=0,021)$.

The third group was made up of the activity "Efficiency" data of line managers and general, special management skills. The assessment of the relationship between the measures was performed using Spearman rank correlation.

The analysis found that there is a statistically significant correlation: "Efficiency" of the activities of line managers of banks with 1. (Stress resistance) $(\mathrm{R}=0,24, \mathrm{p}-\mathrm{level}=0,003), 6$. (Responsibility) $(\mathrm{R}=0,24$, $\mathrm{p}$-level $=0,002)$, 9. $($ Capacity for work $)(\mathrm{R}=0,30$, $\mathrm{p}$-level $=0,000)$, 7. (Discipline) $(\mathrm{R}=0,46$, $\mathrm{p}$-level $=$ $0,000), 8$. (Self-criticism) $(R=0,33$, p-level $=0,000), 11$. (The ability to resolve conflicts $(R=0,22, p$-level $=$ $0,006), 14$. (The ability to adjust the goals of the collective) $(\mathrm{R}=0,23, \mathrm{p}$-level $=0,004), 16$. (The ability to control the performance of employees) $(\mathrm{R}=0,32$, p-level $=0,000), 17$. (Organizational skills) $(\mathrm{R}=0,30$, $\mathrm{p}$-level $=0,000), 18$. (Personal qualities necessary to the manager) $(\mathrm{R}=0,26, \mathrm{p}$-level $=0,000), 19$. (The ability to fairly distribute the work) $(\mathrm{R}=0,38, \mathrm{p}$-level $=0,000), 20$. (Tendency to administrative work) $(\mathrm{R}=0$, 20 , $\mathrm{p}$-level $=0,000)$; "Efficiency" of the activities of line managers of trading companies with 2. (Initiative) $(\mathrm{R}=$ $0,39, \mathrm{p}$-level $=0,000), 4$. (Organization) $(\mathrm{R}=0,35, \mathrm{p}$-level $=0,000), 5$. (Efficiency) $(\mathrm{R}=0,23, \mathrm{p}$-level $=$ $0,000)$, 7. (Self-discipline) $(\mathrm{R}=0,26$, $\mathrm{p}$-level $=0,000), 8$. (Self-criticism) $(\mathrm{R}=0,32$, $\mathrm{p}$-level $=0,000), 11$. (The ability to resolve conflicts) $(\mathrm{R}=0,24, \mathrm{p}$-level $=0,000), 12$. (The ability to formulate goals for the collective) $(\mathrm{R}=$ $0,29$, $p$-level $=0,000), 13$. (The ability to plan his own activities) $(\mathrm{R}=0,35, \mathrm{p}$-level $=0,000), 14$. (The ability to adjust the goals of the collective) $(\mathrm{R}=0,23$, p-level $=0,004), 16$. (The ability to monitor the performance of the employees) $(\mathrm{R}=0,31, \mathrm{p}$-level $=0,000), 19$. (The ability to fairly distribute the work) $(\mathrm{R}=0,39$, $\mathrm{p}$-level $=0,000), 20$. (Tendency to administrative work) $(\mathrm{R}=0,39$, $\mathrm{p}$-level $=0,000)$.

Correlation analysis revealed a number of individual - psychological abilities that determine the "effectiveness" of managerial activities of line managers of banks and trading companies.

To form the quantitative estimates of professiogramms of "effective" line managers of banks and trading companies, we used the results of the Spearman correlation analysis, and Fisher's and the Kolmogorov-Smirnov criteria. As a result, the first part of the empirical research has identified quantitative results of individual psychological characteristics that determine the "effectiveness" of the activities of line managers in the socio professional environment. Based on these results, we formulated professiogramms for line managers of banks and trading companies.

Results of the study of line managers of banks:

1. Individual - psychological characteristics: biographical characteristics: age 30-40 years; work experience of 5 years and personal - psychological qualities (integrated in ten-point scale): (md) self-esteem more than 5.7; (A) communicability more than 7.1 ; (C) emotional stability of more than $7.9 ;(\mathrm{H})$ courage in social contacts more than 7.1; (Q) self confidence less than 5.7; (Q3) high self-control more than 5; emotional instability less than 4.6; (lie scale) more than 3.3; motivation to achievements more than 5.9.

2. Ability of managerial activities (integrated in ten-point scale): stress tolerance more than 8 ; responsibility more than 9; discipline more than 9; self-criticism more than 8 ; work capacity more than 9; the ability to resolve conflicts more than 9; the ability to adjust the goals of employees more than 8 ; the ability to monitor the performance of the employees more than 8 ; organizational skills more than 9 ; personal qualities necessary for manager more than 8 ; fairness in the distribution of responsibilities between the staff more than 8 ; striving to do their job better than that is required more than 9 ; arithmetic means of the results of the questionnaire more than 8.6. 
Results of the study of line managers of trade companies:

1. Individual - psychological characteristics: biographical characteristics: age 30-40 years; work experience of 5 years and personal - psychological qualities (integrated in ten-point scale): (A) communicability more than 5.7; (B) intelligence more than 5; (E) dominance more than 5.7; (F) expressiveness more than 5.7; (G) normative behavior more than 6.4; (I) sensitivity more than 6.4; (L) suspiciousness more than 5.7 ; (M) developed imagination more than 5; (N) diplomacy more than 5.7; (Q1) radicalism more than 5; (Q2) nonconformism more than 5; (Q4) intensity more than 5.7; (scale of neuroticism) emotional instability more than 5.

2. Ability of managerial activities (integrated in the ten-point scale): initiative more than 8 ; organization of more than 9; efficiency more than 8 ; discipline more than 8 ; self-criticism more than 8 ; the ability to resolve conflicts more than 8 ; the ability to formulate goals for the employees more than 9 ; ability to plan his activities more than 9; the ability to adjust the goals of employees more than 8 ; the ability to monitor the performance of the employees more than 8 ; the ability to fairly distribute the work among employees more than 8 ; the desire to do the job better than it is required more than 8 ; arithmetic mean of the results of the questionnaire more than 8.3.

In the second part of the study to verify the objectivity of results professiography we organized and conducted a competitive selection of line managers from applicants in banks and trading companies. Competitive selection of line managers included three stages.

The first stages of the competition - applicants were evaluated according to the analysis of survey data. Applicants whose biographical characteristics were consistent with the results of professiogramms, passed to the second stage.

The second stages of the competition - applicants were evaluated according to the analysis of tests. The results of the applicants were integrated into ten point scales. These data, using correlation analysis, $\mathrm{p}<0.05$, were compared with the results of professiogramms. Applicants, whose personal - psychological qualities corresponded to the results of professiogramm, passed to the third stage.

The third stage of the competition - applicants were evaluated according to the results of the candidates' interview (expert group). These data, using correlation analysis, $\mathrm{p}<0.05$, were compared with the results of professiogramms. Applicants, whose managerial skills correspond to the results of professiogramms, were taken on the work on probation.

\section{Discussions}

Empirical research has allowed building a complete system of practical work under copyright methodological tools on an objective assessment and competitive selection of line managers.

For the analysis of the deferred results of managerial activities of the experimental and control groups of line managers, we used the Fisher and Kolmogorov-Smirnov criteria. The analysis has showed that in the experimental groups of banks and trading companies (selected by copyright methodological tools), there are more "effective" line managers than in the control groups (selected by a usual methods for management).

The analysis of deferred results of line managers revealed that in the workers' association managed by line managers, selected using the author's methodological tools, the total number of days of absence of employees on sick leave in the year reduced by $9 \%$, and the results of the plan fulfillment increased by $14 \%$. In other words, we can say that the optimization of the managerial activities of line managers, improved the performance of companies, their individual services, professionals and workers.

\section{Conclusions}

Thus, the data received in this study, have a clear practical orientation and form the basis of psychological work in the study individual - psychological abilities of line managers, taking into account the socio - professional environment of the subject. Based on the data obtained in our study, with a certain degree of probability, we can make the following conclusions:

1. The analysis of survey data found that the "effective" line managers of banks and trading companies are characterized by the age of 30-40 years and work experience of more than 5 years.

2. An analysis of the personal - psychological qualities found that "effective" line managers of banks are characterized by self-esteem, communicability, emotional stability, courage in the field of social contacts, self-confidence, high self-control, emotional instability demonstrativeness; achievement motivation, and the "effective" line managers of trade companies are characterized communicability, intelligence, dominance, expressivity in behavior, sensitivity, suspiciousness, developed imagination, diplomacy, radicalism, non-conformism, tension, emotional instability. 
3. As a result of the analysis of the abilities to managerial activity we found that "effective" line managers of banks are characterized by resistance to stress, responsibility, discipline, self-criticism, efficiency, the ability to resolve conflicts, the ability to adjust the goals of the employees, the ability to monitor the performance of the employees, organizational skills, personal qualities necessary to the manager, equity in the distribution of responsibilities between the staff, and the desire to do their job better than it is required "effective" line managers of trade companies are characterized by initiative, organization, diligence, discipline, self-criticism, the ability to resolve conflicts, the ability to formulate goals for the employees, the ability to plan their activities , the ability to adjust the goals of the employees, the ability to monitor the performance of the employees, the ability to fairly distribute the work among employees, the desire to do the job better than it is required.

4. Quantitative results of individual psychological abilities that we received in the empirical study allow us to formulate a professiogramm of line managers with regard to their effectiveness in socio-professional activities' conditions.

5. The study of individual psychological abilities that influence managerial activities, allowed formulating methodological tools for objective assessments of line managers who are able to reveal their managerial capacity in socio-professional activities' conditions.

6. Analysis of the results of the study of individual psychological abilities revealed that managerial abilities and individual psychological characteristics define the "effective" of managerial activities of line managers.

\section{References}

Abulkhanova-Slavskaya, K. A. (1980). Activities and personality psychology. M.: Nauka.

Alaverdov, A. R. (2008). Personnel management in commercial bank. M.: Market DS.

Ananev, B. G. (2005). Psychological problems of human study: Selected psychological works. M.: Publishing House of Moscow Psychological and Social Institute; Voronezh: Publisher NPO "MODEK".

Andreeva, G. M. (2006). Social psychology. M.: Aspect Press.

Bazarov, T. Y. (2005). Personnel Management. M.: Publishing Center "Academy".

Kabachenko, T. S. (2005). Management Psychology. M.: Pedagogical Society of Russia.

Karpov, A. V. (2003). Work Psychology. M.: Publishing House of VLADOS PRESS.

Karpov, A. V. (2004). Psychology of Management. M.: Gardariki.

Klimov, E. A. (1998). Introduction to the psychology of work. M.: Culture and Sports, UNITY.

Kurtikov, N. A. (2007). Psychology and Sociology of Management. State University of Management.

Leontiev, A. N. (1983). Selected psychological works. In 2 t. M.: Pedagogy.

Lomov, B. F. (1981). On the problem of activity in psychology, Journal of Psychology, 2(5), 9-18.

Morozov, A. V. (2008). Managerial Psychology. Academic Project Fund "Mir".

Parigin, B. D. (2003). Social psychology. SPb.: SPbGUP.

Platonov, K. K. (1972). Problems of abilities. Publishing House "Nauka".

Pryazhnikov, N. S., \& Pryazhnikova, E. J. (2004). Psychology of work and human dignity.

Rozanova, V. A. (2006). Psychology of managerial activities. M.: Publishing house "Alfa-Press".

Rubinstein, S. L. (2002). Fundamentals of general psychology. St.: Peter.

Samoukina, N. V. (2003). Personnel management: the Russian experience. SPb.: Peter.

Shadrikov, V. D. (1994). Activities and abilities. M.: Logos.

Suvorova, G. A. (2003). Activities Psychology. M.: Perce.

Tolochek, V. A. (2005). Modern psychology of labor. SPb.: Peter.

Zhuravlev, A. L. (2005). Psychology of joint activities. Publishing House of the "Institute of Psychology RAS".

\section{Copyrights}

Copyright for this article is retained by the author(s), with first publication rights granted to the journal.

This is an open-access article distributed under the terms and conditions of the Creative Commons Attribution license (http://creativecommons.org/licenses/by/3.0/). 